\title{
Academics across Europe join 'Brexit' debate
}

\section{If the United Kingdom leaves the EU, researchers throughout the bloc will feel the effects.}

\section{BY DANIEL CRESSEY}

A UK debate over whether to leave the European Union (EU) is drawing in academics from across the continent. Millions in research funding, collaborations and the employment status of thousands of scientists could be affected by the outcome. The UK government has committed to holding a referendum on a Brexit - as the possible British exit has been dubbed - by the end of 2017 .

Brexit proponents say that a lone United Kingdom would enjoy greater freedom to set policies that affect research. But most researchers who are willing to pick a side publicly are worried about the prospect. "Europe would suffer and the UK would suffer," says Lesley Wilson, secretary-general of the European University Association in Brussels.

One big uncertainty is money. UK universities rely on the EU for around $16 \%$ of their total research funding. And scientists working in the United Kingdom are disproportionately successful at winning such awards compared to applicants in other member states; under the EU's last Framework Programme, which ran from 2007 to 2013, they won grants worth $€ 7$ billion (US $\$ 7.58$ billion), second in value only to Germany. UK institutions also host more researchers with grants from the EU-funded European Research Council (ERC) than those in any other member state.

Being outside the EU does not necessarily preclude involvement in EU programmes. Non-members such as Norway, Switzerland and Israel have gained access to various EU research schemes, mainly by paying for inclusion in them and by adopting some general EU rules, such as freedom of movement.

Angus Dalgleish, who is part of the 'Leave.eu' campaign, says that the shortfall would be made up if the United Kingdom were to redirect to science even a portion of the sum - most recently around $€ 17$ billion - that it must contribute annually to the overall budget of the EU as a member. "We would have a far bigger budget for funding our own science," says Dalgleish, a cancer and HIV researcher at St George's, University of London, who once stood for election as a member of the pro-Brexit UK Independence Party.

But opponents of a Brexit counter that the United Kingdom could find it expensive to renegotiate entry into EU funding

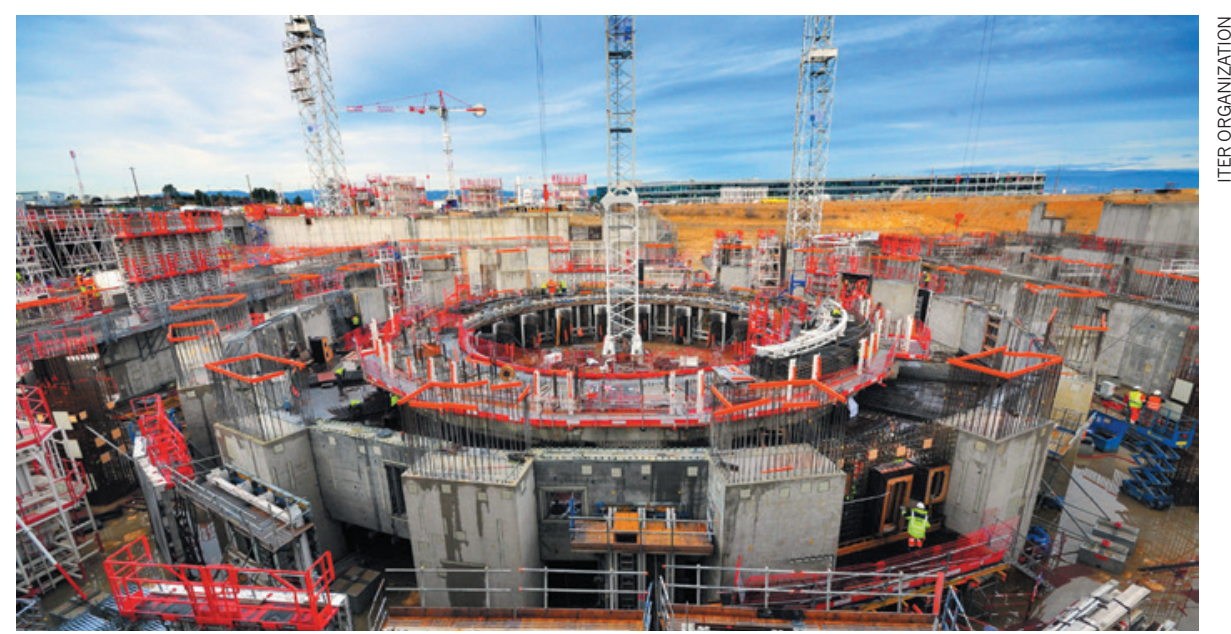

The fusion reactor ITER in France could become less accessible to UK scientists in the event of a Brexit.

programmes because of its historically outsized success at winning competitive grants. They also cite the example of Switzerland, which had bought into EU funding schemes but was booted out of many such projects in 2014 after its citizens voted to restrict immigration. Scientists had to scramble to find ways around the official severing of ties after that, and Swiss participation has been restricted ever since.

UK researchers could still access major EU research-infrastructure projects after a Brexit. But they would lose the priority given to EU members, putting them at the back of the queue for access to facilities ranging from a laser instrument to a major social-science data set. UK researchers would also have to negotiate for access to international projects where EU funding currently gets them in, such as the huge experimental fusion reactor, ITER.

\section{BRIDGES BURNED}

For Kurt Deketelaere, secretary-general of the League of European Research Universities in Leuven, Belgium, the potential loss of mobility and collaboration is worrying for scientists across Europe. Wilson agrees. "Everybody wants to work with the best," she says. "If you're going to lose strong partners, that's not going to benefit anybody." Dalgleish counters that universities already maintain successful collaborations with non-EU members, and says that opting out would have "no negative impact on scientific collaboration whatsoever".
Still, around $15 \%$ of academic staff at UK institutions are non-UK EU nationals, a figure that rises to $20 \%$ among elite universities. It is unlikely that these people would have to apply for visas or leave in the event of a Brexit, or that grants already awarded would be clawed back. But in future, obtaining funding and securing jobs across UK-EU borders could become more difficult. "In general, the UK would be less attractive for me," says Yvonne Peters, a particle physicist originally from Germany who works at the University of Manchester, UK, and is partially funded by a grant from the ERC.

Brexit proponents say that if the United Kingdom leaves, it will escape other EU regulations, such as rules governing clinical trials. These have been widely blamed for hindering UK medical research - triggering proposals to overhaul the regulations. The nation might also be able to offer more tax credits for research spending and adopt a more positive stance on genetically modified crops.

But the EU would also lose a powerful political voice pushing for science, says Vicky Ford, a UK Conservative Party member of the European Parliament who supports EU reform. She says that UK votes have been crucial in parliamentary decisions that have affected the entire bloc, including reductions to red tape in the awarding of funds, and improvements to science-advice mechanisms in EU politics. Without UK votes, Ford says, EU research would have paid a price: "Definitely there would have been less money." - SEE EDITORIAL P.6 


\section{CORRECTION}

The News story 'Academics across Europe join 'Brexit' debate' (Nature 530, 15; 2016) gave the wrong amount for how much the United Kingdom must contribute to the EU budget as a member - it is around $€ 17$ billion. And it should have made it clear that Brexit would mean that the United Kingdom would have to renegotiate access to ITER but that it wouldn't necessarily go to the back of the queue. 